\title{
KEBIJAKAN PROFESI GURU MADRASAH MELALUI PROGRAM SERTIFIKASI DALAM MENINGKATKAN KUALITAS PENDIDIKAN ISLAM
}

\author{
Sigit Tri Utomo \\ Sigit.triutomo@yahoo.com \\ STAI Nahdlatul Ulama Temanggung Jawa Tengah
}

DOI: 10.21580/wa.v6i1.4143

\begin{abstract}
Educators are human resources who contribute in the exploration of students at an educational institution. In general, educators should have four competencies such as professional competence, paedagogik competence, personality competence, and social competence. As an educator who has the task of developing the potential of learners, it is clear that a teacher should improve his ability with various efforts, including by writing, discussing, following scientific activities, following seminars, and other activities that are able to hone his noble duty as an educator. Because some competencies to be developed are social competence, competence, pedagogy, and professional competence. A good teacher is those who meet the requirements of professional skills either as educators. Herein lies the importance of teachers' professional quality standards to ensure the quality of teaching and learning process.In addition to being a professional educator, with the certification of teachers is expected to be an economically prosperous educator. In addition to the economic welfare it will obviously increase the motivation of teachers to develop their professional tasks through several activities such as delegation of subject teachers work (MGMP), KKG, seminars, discussion activities and even motivation to continue higher education. Because of the cost of functional allowance to teachers who have passed a certified teacher can really focus on the task of becoming an educator in an effort to educate the nation by no longer thinking about the family economy that has been the burden of teachers in Indonesia. Because we know there are still many teachers who are still far from welfare. Many who have a double profession other than to be a teacher like a buyer of used goods, public transportation drivers, newspaper delivery, fried sellers, and so forth. So ultimately the dignity of a teacher can occupy at the highest social stratification through this certification program.

Methods of data collection in this study using literature study. In this stage, the researchers try to select the data (books) that have relevance to the professional
\end{abstract}


policy of madrasah teachers through certification program in improving the quality of Islamic education. Then the authors also use the synthesis analysis that is by handling of certain scientific objects by combining the understanding of one with another understanding, which ultimately can be obtained by the new knowledge of professional policy of madrasah teachers through certification program in improving the quality of Islamic education. The author also uses content analysis that is research conducted on the information documented in the recording, good pictures, sounds, writings and others.

With this method will be done data analysis and processing scientifically about the content of writing policy of the profession of madrasah teachers through certification program in improving the quality of Islamic education research results indicate that the government certification to teachers intended as an effort to project teachers into educators who are actually able to do their duties with good and professional who have a predetermined standard of competence. Specifically, the objectives of teacher certification are: To improve the competence of madrasah teachers in their field of knowledge, to strengthen the teaching ability of madrasah teachers, to develop madrasah teacher competence holistically so as to be able to act professionally and improve the ability of Madrasah teachers in scientific research and activity activities, information communication technology for learning purposes.

Keywords: Profession Policy of Madrasah Teachers, Certification, Quality of Islamic Education

\begin{abstract}
Abstrak
Pendidik merupakan SDM yang memberikan sumbangsih dalam ekplorasi peeserta didik di sebuah lembaga pendidikan. Secara umum pendidik harus mempunyai empat kompetensi seperti kompetensi profesional, kompetensi paedagogik, kompetensi kepribadian, dan kompetensi sosial.

Sebagai pendidik yang memiliki tugas pengembangan potensi peserta didik, jelaslah seorang guru harus mengimprovisasikan kemampuannnya dengan berbagai upaya, diantaranya dengan menulis, berdikusi, mengikuti kegiatan ilmiah, mengikuti kegiatan seminar, dan kegiatan yang lain yang mampu mengasah tugas mulianya sebagai pendidik. Karena beberapa kompetensi yang harus dikembangkan adalah kompetensi sosial, kompetensi, pedagogik, dan kompetensi profesional. Seorang guru yang baik adalah mereka yang memenuhi persyaratan kemampuan profesional baik sebagai pendidik. Disinilah letak pentingnya standar mutu profesianal guru untuk menjamin proses belajar mengajar dan hasil yang bermutu. ${ }^{1}$
\end{abstract}

\footnotetext{
${ }^{1}$ Anwar Jasin, Pengembangan Standar Profesional Guru dalam Rangka Peningkatan Mutu Sumber Daya Manusia, dalam M. Dawam Rahajo, (ed.), Keluar dari Kemeut Pendidikan Nasional: Menjawab Tantangan Kualitas Sumber Daya Manusia Abad (SDM) 21, (Jakarta: PT Intermasa, 19970, hlm. 25.
} 
Selain menjadi tenaga pendidik profesional, dengan adanya sertifikasi guru diharapkan seorang pendidik secara ekonomi menjadi sejahtera. Selain itu dengan adanya kesejahteraan ekonomi jelaslah akan meningkatkan motivasi guru untuk mengembangkan tugas keprofesionalitasnya melalui beberapa kegiatan seperti musyawarah kerja guru mata pelajaran (MGMP), KKG, seminar, kegiatan diskusi bahkan motivasi untuk melanjutkan pendidikan yang lebih tinggi. Karena adanya biaya tunjangan fungsional kepada guru yang telah lulus tersertifikasi seorang guru bisa benar-benar fokus dalam tugasnya menjadi pendidik dalam upaya mencerdaskan bangsa dengan tidak lagi memikirkan ekonomi keluarga yang selama ini menjadi beban para guru di Indonesia. Karena kita tahu saat ini masih banyak guru yang masih jauh dari kesejahteraan. Banyak yang mempunyai profesi ganda selain menjadi guru seperti tukang pembeli barang bekas, sopir angkot, loper koran, penjual gorengan, dan sebagainya. Sehingga pada akhirnya martabat seorang guru dapat menduduki pada stratifikasi sosial tertinggi melalui progam sertifikasi ini. Metode pengumpulan data dalam penelitian ini menggunakan studi pustaka. Dalam tahapan ini, peneliti berusaha menyeleksi data-data (buku) yang ada relevansinya dengan kebijakan profesi guru madrasah melalui program sertifiikasi dalam meningkatkan kualitas pendidikan Islam. Kemudian penulis juga menggunakan analisis sintesis yaitu dengan penanganan terhadap objek ilmiah tertentu dengan jalan menggabungkan pengertian yang satu dengan pengertian lain, yang pada akhirnya dapat diperoleh pengetahuan yang sifatnya baru kebijakan profesi guru madrasah melalui program sertifiikasi dalam meningkatkan kualitas pendidikan Islam. Penulis juga menggunakan content analysis yaitu penelitian yang dilakukan terhadap informasi yang didokumentasikan dalam rekaman, baik gambar, suara, tulisan dan lain-lain.

Dengan metode ini akan dilakukan analisis data dan pengolahan secara ilmiah tentang isi tulisan kebijakan profesi guru madrasah melalui program sertifiikasi dalam meningkatkan kualitas pendidikan Islam hasil penelitian menunjukkan bahwa pemerintah melakukan sertifikasi kepada guru dimaksudkan sebagai upaya memproyeksikan guru menjadi tenaga pendidik yang benar-benar mampu melakukan tugasnya dengan baik dan profesional yang mempunyai standar kompetensi yang telah ditentukan. Jika dipaparkan secara spesifik, maka tujuan sertifikasi guru adalah: ${ }^{2}$ Meningkatkan kompetensi guru madrasah dalam bidang ilmunya, memantapkan kemampuan mengajar guru madrasah, mengembangkan kompetensi guru madrasah secara holistik sehingga mampu berindak secara profesional serta meningkatkan kemampuan guru Madrasah dalam kegiatan penelitian dan kegatan ilmiah, serta memanfaatkan teknologi komunikasi informasi untuk kepentingan pembelajaran

${ }^{2}$ Ihkwanah, Bunga Rampai Pendidikan Islam (Surabaya: Taruna Media Pustaka, 2011), hlm. 230. 
Kata kunci: Kebijakan Profesi Guru Madrasah, Sertifikasi, Kualitas Pendidikan Islam

\section{A. Pendahuluan}

Pendidikan adalah upaya mencerdaskan kehidupan bangsa. Dengan pendidikan yang berkualitas tentunya akan menjadikan manusia unggul yang mampu berkompetesi di era modernisasi seperti sekarang ini. Kualitas pendidikan tidak terlepas dengan adanya faktor pendidik yang profesional dalam menjalankan tugasnya. Akhir-akhir ini upaya pemerintah dalam meningkatkan profesionalitas dan kesejahteraan guru telah dilakukan secara serius. Hal ini terbukti dengan adanya bentuk kebijakan pemerintah dalam program sertifikasi.

Terkait dengan sertifikasi guru, ternyata negara-negara maju seperti Amerika melalui badan independen yang disebut The American Association of College for Teacher Education (AACTE). Badan tersebut berwenang menilai dan menentukan ijazah yang dimiliki pendidik, layak atau tidak layak untuk diberi lisensi pendidik. Sertifikasi guru juga telah dibelakukan di Cina sejak tahun 2001 dan jepang ternyata sudah memberlakukan sertifikasi guru selama 33 tahun. Sejak tahun 1974. Diyakini bahwa kemajuan Jepang bahwa kemajuan bangsanya diawali melaui pendidikan. ${ }^{3}$

Karena itu, sikap profesionalitas guru dalam dunia pendidikan (sekolah) tidak sekedar dinilai formalitas tetapi juga harus fungsional dan menjadi prinsip dasar yang melandasi aksi operasionalnya. Tuntutan demikian ini wajar karena dalam dunia modern, khususnya dalam rangka persaingan global, memerlukan sumber daya manusia yang bermutu dan selalu melakukan improvisasi diri secara terus menerus. Sehingga dapat dikatakan bahwa tenaga pendidik atau guru merupakan cetak biru (blue print) bagi penyelenggaraan pendidikan. ${ }^{4}$

Seorang guru yang baik adalah mereka yang memenuhi persyaratan kemampuan profesional baik sebagai pendidik. Disinilah letak pentingnya standar mutu profesianal guru untuk menjamin proses belajar mengajar dan hasil yang bermutu. ${ }^{5}$

Akan tetapi dalam upaya pemerintah melakukan program sertifikasi guru menuai prokontra dari berbagai pihak. Beberapa pihak yang pro berargumen bahwa sertifikasi guru adalah jalan menuju peningkatan kualitas seorang pendidik dan kesejahteraan, adapun yang kontra mereka berargumen bahwa program sertifikasi mengahambur-hamburkan APBN untuk pendidikan. Belum lagi masalah diklat program sertifikasi yang setiap tahun mengalami perubahan seperti program di Kemenag yang tahun 2010 menggunakan sistem PLPG (Program Pelatihan Profesi Keguruan) portofolio, di tahun 2011 dan 2012 diklat

${ }^{3}$ Masnur Muslich, Sertifikasi Guru Menuju Profesionalisme Pendidik (Jakarta: PT Bumi Aksara, 2007) hlm. 4 .

${ }^{4}$ Mujtahid, Pengembangan Profesi Guru (Malang: UIN Maliki Press, 2009), hlm. 5.

${ }^{5}$ Anwar Jasin, Pengembangan Standar Profesional Guru dalam Rangka Peningkatan Mutu Sumber Daya Manusia, dalam M. Dawam Rahajo, (ed.), Keluar dari Kemeut Pendidikan Nasional: Menjawab Tantangan Kualitas Sumber Daya Manusia Abad (SDM) 21, (Jakarta: PT Intermasa, 19970, hlm. 25. 
PLPG selama 10 hari, dan tahun 2013 adalah PPG (program profesi guru) dengan diklat 1 tahun akan tetapi secara praktik hanya dilakukan sekitar 6 bulan dengan dibiayai oleh kemenag, belum selesai PPG Kemenag sudah mensosialisakan PKG (Program Kompetensi Guru) untuk 40.000 guru yang belum tersertifikasi.

\section{B. Pembahasan}

\section{Profesionalisme Guru}

Guru merupakan salah satu figur yang memberi kontribusi besar dalam dunia pendidikan. Karena dengan adanya bimbingan guru peserta didik mampu mengembangkan potensi yang dimiliki, bahkan meraih prestasi.

Guru sebagian salah satu komponen di sekolah menempati profesi yang memainkan peranan penting dalam proses belajar mengajar. Kunci keberhasilan sekoah dalam mencaai tujuan pendidikan sekolah dalam mencapai tujuan di lembaga pendidikannya ada di tangan guru. Ia mempunyai peranan dalam proses pertumbuhan dan perkembangan peserta didiknya, pengetahuan, keterampilan dan kecerdasan dan sikap serta pandangan hidup peserta didik. Oleh karenanya, masalah sosok guru yang dibutuhkan adalah seorang pendidik yang yang dapat membantu pertumbuhan dan perkembangan peserta didik sesuai dengan tujuan-tujuan pendidikan yang diharapkan pada setiap jenjang sekolah. ${ }^{6}$

Profesionalisme guru bisa dilihat juga dari kesesuaian (fitness) atau relevansi keluarga pendidikan dengan profesi yang disandangnya. Dalam bahasa yang lain dapat dikatakan bahwa, profesionalisme guru sama halnya dengan "skilled performer" (pelaku yang terampil), seorang guru profesional dapat tampil dengan penuh perkasa, inovatif, original, dan invensif. Profesionalisme guru bisa ditilik dari sejauhmana ia menguasai prinsip-prinsip pedagogis secara umum maupun didaktik-metodik secara khusus yang berlaku pada setiap pelajaran. ${ }^{7}$

Menurut Omar Hamalik, tugas profesionalisme guru antara lain:

1. Bertindak sebagai model bagi para anggotanya.

2. Merangsang pemikiran dan tindakan.

3. Memimpin perancanaan dalam mata pelajaran.

4. Memberikan nasehat kepada executive teacher sesuai dengan kebutuhan tim.

5. Membina dan memelihara literatur profesional dalam daerah pelajarannya.

6. Bertindak atau memberikan pelayanan sebagai manusia sumber dalam daerah pelajaran tertentu dengan referensi pada training dan pengembangan kurikulum.

7. Memelihara hubungan dengan orang tua peserta didik.

8. Bertindak sebagai pengajar dalam timnya. ${ }^{8}$

\footnotetext{
${ }^{6}$ Burhanuddin, dkk. Profesi Keguruan, (Malang, IKIP malang, 1995) hlm. 20.

${ }^{7}$ Dedi Supriadi, Mengangkat Citra dan Martabat Guru, (Yogyakarta: Adicita Karya Nusa, 1998), hlm.93.

${ }^{8}$ Omar Malik, Pendidikan Guru, Konsep dan Strategi, (Bandung: Mandar maju, 1991), hlm 32
} 
Profesionalisme guru sesungguhnya sejalan dengan-cita reformasi pendidikan saat ini. Karena itu, profesionalisme guru pada hakikatnya adalah profil yang mampu beradaptasi dengan tuntutan dan perubahan zaman. Kriteria sebagi profil (profesionalisme guru) yang mampu menyesuaikan dengan perubahan itu diantaranya:

1) Pemanfaatan semaksimal mungkin sumber belajar.

2) Perombakan secara struktural hubungan antara guru dan peserta didik seperti hubungan pertemanan.

3) Penggunaan teknologi pendidikan modern dan penguasaan iptek.

4) Kerja sama dengan teman sejawat dan antar sekolah.

5) Kerja sama dengan komunitas lingkungannya, dan lain sebagainya.

Berdasarkan uraian di atas, guru merupakan suatu pekerjaan atau jabatan profesi yang mempunyai tugas tidak ringan. Secara eksplisit guru memilki tugas selain menjadi mitra bagi lembaga sekolah, bagi teman seprofesi, yang dituntut mempunyai keterampilan dan keahlian yang mampu menciptakan produktivitas atau lulusan yang memiliki kompetensi yang baik. Selanjutnya sebagai seorang pendidik dalam melakukan kegiatan pengembangan dan bimbingan mental dan spiritual (rohaniah, moral dan spiritual), pengembangan intelektual (kecerdasan dan kognitif) dan pengembangan pada bidang keterampilan (psikomotorik). Seorang pendidik, yakni guru berkewajiban melaksanakannya secara efesien dan efektif.

Adapun menurut Undang-Undang Nomor 14 Tahun 2005 tentang Guru dan Dosen Bab 3 pasal 7 dinyatakan bahwa prinsip profesionalitas guru sebagai berikut:

1. Memiliki bakat, minat, panggilan jiwa dan idealisme.

2. Memilki komitmen untuk meningkatkan mutu pendidikan, keimanan dan ketakwaan serta akhlak mulia.

3. Memiliki kualifikasi akademik dan latar belakang pendidikan sesuai dengan bidang tugas.

4. Memiliki kompetensi yang diperlukan sesuai dengan bidang tugas.

5. Memiliki tanggung jawab atas pelaksanaan tugas keprofesionalan.

6. Memilki penghasilan yang ditentukan sesuai dengan prestasi kerja.

7. Memiliki kesempatan untuk untuk mengembangkan keprofesionalan secara berkeberlanjutan dengan belajar sepanjang hayat.

8. Memilki jaminan perlindungan hukum dan melaksanakan tugas keprofesionalan.

9. Memiliki organisasi profesi yang mempunyai kewenangan mengatur hal-hal berkaitan dengan keprofesionalitas guru.

Dari rumusan di atas diharapkan bahwa landasan guru dalam pelaksanaannya di lembaga pendidikan menjadi tenaga profesional guna meningkatkan martabat dan peran guru sebagai agen pembelajaran yang selanjutnya meningkatkan mutu pendidikan nasional. 


\section{Sertifikasi Guru Madrasah}

Salah satu isu bentuk kebijakan pendidikan yang masih sering di bicarakan adalah disahkannya Undang-Undang No 14. Tahun 2005 tentang guru dan dosen pada tahun 2005 adalah persoalan sertifikasi. Berbagai interpretasi terkait dengan pemahaman sertifikasi bermunculan. Ada yang memahami bahwa guru yang sudah memiliki jenjang S1 kependidian secara otomatis sudah bersertifikasi, ada juga yang memahami bahwa sertifikasi hanya dapat diperoleh melalui pendidikan khusus yang dilakukan oleh Lembaga Pendidikan Tenaga Kependidikan (LPTK) yang ditunjuk pemerintah. ${ }^{9}$ Kesalahpahaman mereka tersebut mulai mereda setelah diterbitkannya Permendiknas RI No. 18 tahun 2007 tentang sertifikasi bagi guru dalam jabatan tanggal 4 Mei 2007 dan keputusan Menteri Pendidikan Nasional RI No. 057/0/207 tentang penetapan perguruan tinggi penyelenggara sertifikasi bagi guru dalam jabatan. ${ }^{10}$

Agar pemahaman tentang sertifikasi lebih jelas, coba kita pahami beberapa UU RI No. 14 tahun 2005 tentang guru dan dosen seperti berikut ini: ${ }^{11}$

a. Pasal 1 butir 11 yang berbunyi: sertifikasi adalah proses pemberian sertifikat kepada pendidik kepagda guru dan dosen.

b. Pasal 8: Guru wajib memiliki kualifikasi akademik, kompetensi, sertifikasi pendidik, sehat jasmani dan rohani, serta memiliki kemampuan untuk mewujudkan tujuan pendidikan nasional.

c. Pasal 11 butir 1: sertifikat pendidik sebagimana terdapat dalam pasal 8 diberikan kepada guru yang telah memenuhi persyaratan.

d. Paal 16: Guru yang memiliki sertifikat pendidik memperoleh tunjangan profesi sebesar satu kali gaji, guru negeri maupun swasta dibayar pemerintah.

Dengan demikian, sertifikasi adalah proses pemberian sertifikat pendidik kepada guru yang telah memenuhi persyaratan tertentu, yaitu memiliki kualifikasi akademik, kompetensi, sehat jasmani dan rohani, serta memiliki kemampuan untuk mewujudkan tujuan pendidikan nasional, yang dibarengi dengan peningkatan kesejahteraan yang layak.

Adapun dasar hukum sertifikasi guru adalah sebagai berikut: ${ }^{12}$

a. Undang-undang RI Nomor 20 tahun 2003 tentang Sistem Pendidikan Nasional

b. Undang-undang RI Nomor 14 tahun 2005 tentang Guru dan Dosen

c. Peraturan pemerintah RI Nomor 19 tahun 2005 tentang Standar Nasional Pendidikan

d. Peraturan menteri pendidikan Nasional Nomor 16 tahun 2005 tentang Standar Kualifikasi dan Kompetensi Pedagogik hlm 5 .

${ }^{9}$ Masnur Muslich, Sertifikasi Guru Menuju Profesionalisme Pendidik(Jakarta: Bumi Aksara, 2007),

${ }^{10}$ Masnur Muslich, Sertifikasi Guru...hlm. 2.

${ }^{11}$ Departemen Pendidikan Nasional. Undang-Undang RI No 14 tahun 2005 tentang Guru dan Dosen. (Bandung: Citra Umbara, 2009)

${ }^{12}$ Ihkwanah, Bunga Rampai Pendidikan Islam (Surabaya: Taruna Media Pustaka, 2011), hlm 228. 
e. Fatwa/ pendapat hukum Menteri Hukum dan Hak Asasi Manusia Nomor I. UM. $01.02-253$

f. Permendiknas Nomor 18 tahun 2007 tentang Sertifikasi Guru dalam jabatan

g. Permendiknas nomor 40 tahun 2007 tentang sertifikasi guru dalam jabatan melalui jalur pendidikan

h. Pedoman sertifikasi guru dalam Jabatan untuk Lembaga Kependidikan dan Tenaga Kependidikan, Dinas Pendidikan Provinsi, Dinas Pendidikan Kabupaten/Kota.

Secara formal, UU RI Nomor 20 tahun 2003 tentang sisdiknas, UU RI No. 14 tahun 2005 tentang guru dan dosen, dan PP no 19 tahun 2005 tentang standar Nasional Pendidikan menyatakan bahwa guru adalah tenaga profesional. Sebagai tenaga profesional, disyaratkan memiliki kualifikasi akademik S1 atau D4 dalam bidang yang relevan dengan mata pelajaran yang diampunya dan menguasai kompetensi sebagai agen pembelajaran. Pemenuhan persyaratan kualifikasi akademik S1 atau D4 dibuktikan dengan adanya ijasah yang diperoleh di perguruan tinggi pada bangku kuliahnya. Persyaratan relevansi dibuktikan dengan kesesuaian antar bidang pendidikan yang dimiliki dan mata pelajaran yang diampu di sekolah. Selanjutnya, persyaratan penguasaan kompetensi sebagai agen pembelajaran yang meliputi kompetensi kepribadian, kompetensi pedagogik, kompetensi profesional, dan kompetensi sosial dibuktikan dengan sertifikat pendidik.

Peserta sertifikasi guru melalui jalur pendidikan diorientasikan bagi guru yang benarbenar memiliki kompetensi dan mengajar di atau madrasah. Peserta diusulkan oleh kepala madrasah melalui PPPA kecamatan setelah disetujui oleh mapenda kota atau kabupaten untuk madrasah Ibtidaiyah, sedangkan untuk Madrasah Tsanawiyah dan Madrasah Aliyah diusulkan kepala Madrasah melalui mapenda provinsi dengan persyaratan tertentu. Seleksi administrasi dilakukan oleh mapenda di masing masing wilayah. Sedangkan seleksi akademik dilakukan oleh LPTK difasilitasi Ditjen Dikti, sebagaimana aturan yang telah ditetapkan. ${ }^{13}$ Sertifikasi guru dalam dunia pendidikan dalam hal ini madrasah, tentunya tujuan dan beberapa manfaat. Untuk lebih jelasnya akan diuraikan seperti dibawah ini.

\section{Hasil dan Pembahasan}

\section{Tujuan dan Manfaat Sertifikasi Guru di Madrasah}

Pemerintah melakukan sertifikasi kepada guru dimaksudkan sebagai upaya memproyeksikan guru menjadi tenaga pendidik yang benar-benar mampu melakukan tugasnya dengan baik dan profesional yang mempunyai standar kompetensi yang telah ditentukan. Jika dipaparkan secara spesifik, maka tujuan sertifikasi guru adalah sebagai berikut: ${ }^{14}$

1. Meningkatkan kompetensi guru madrasah dalam bidang ilmunya.

${ }^{13}$ Khareuddin dan Mahfudz Junaedi, Kurikulum Tingkat Satuan Pendidkan dan Implementasinya di Madrasah (Semarang: MDC Jateng Kerjasama dengan pilar Media Yogyakarta, cet.II, 2007) hlm 59.

${ }^{14}$ Ihkwanah, Bunga Rampai...hlm. 230. 
2. Memantapkan kemampuan mengajar guru madrasah.

3. Mengembangkan kompetensi guru madrasah secara holistik sehingga mampu bertindak secara profesional.

4. Meningkatkan kemampuan guru Madrasah dalam kegiatann penelitian dan kegatan ilmiah, serta memanfaatkan teknologi komunikasi informasi untuk kepentingan pembelajaran.

Senada dengan pernyataan diatas, Suyatno juga memaparkan bahwa tujuan utama sertifikasi adalah sebagi berikut: ${ }^{15}$

1. Menentukan kelayakan guru dalam melaksanakan tugas sebagi agen pembelajaran dan mewujudkan tujuan pendidikan nasional.

Agen pembelajaran berarti pelaku proses pembelajaran jika belum layak maka seorang guru perlu mengikuti pendidikan formal tambahan atau pelatihan keprofesian pendidik, dan sebaginya.

2. Meningkatkan proses dan mutu hasil pendidikan.

Mutu peserta didik sebagai hasil proses pendidikan akan sangat ditentukan oleh kecerdasan, minat dan upaya peserta didik bersangkutan. Kualitas peserta didik juga ditentukan oleh mutu guru dan mutu proses pembelajaran.

3. Meningkatkan martabat guru.

Dengan segala pendidikan formal dan pelatihan yang telah diikuti, diharapkan guru mampu "memberi" lebih banyak kepada kemajuan siswa. Dengan memberi lebih banyak, martabat kita sebagai guru akan meningkat.

4. Meningkatkan profesionalitas guru.

Mutu profesionalitas guru banyak ditentukan oleh pendidikan, pengalaman, pelatihan, pengembangan diri lain oleh guru yang bersangkutan. Sertifikasi guru hendaknya dapat kita jadikan sebagai langkah awal menuju guru yang profesional.

Adapun manfaat sertifikasi guru antara lain:

1. Melindungi profesi guru dari praktik-praktik yang tidak kompeten, yang dapat merusak citra profesi guru.

Saat ini guru dituntut menerapkan teori dan praktik pendidikan yang telah teruji ke dalam pembelajaran di kelas. Misalnya, untuk mendisiplinkan dan pembelajaran peserta didik, guru lebih memilih pendisiplinan menurut teori kependidikan dan psikologi utama. Bukan dengan melakukan kekerasan seperti pemukulan dan sebagainya.

2. Melindungi masyarakat dari praktik-praktik pendidikan yang tidak berkualitas dan tidak profesional.

Mutu pendidikan disekolah ditentukan oleh mutu guru dan mutu guru serta proses pemeblajaran di kelas. Melalui sertifikasi, masyarakat akan menilai sekolah tertentu berdasarkan mutu kedua faktor ini.

\footnotetext{
${ }^{15}$ Suyatno, Panduan Sertifikasi Guru (Jakarta: PT Indeks, 2008), hlm. 2.
} 
3. Meningatkan kesejahteraan guru.

Hasil sertifikasi guru dapat dengan mudah digunakan untuk menentukan besarnya imbalan yang pantas diberikan kepada masing-masing guru. Dengan sertifikasi guru, dapat terhindar dari guru yang berprestasi dan kompeten akan tetapi mendapat imbalan kecil. Sebaliknya akan terhindar dari guru yang tidak kompeten atau memiliki kompetensi rendah mendapat imbalan besar. ${ }^{16}$

Abdulllah dan Toto juga memaparkan manfaat dari sertifikasi adalah sebagai berikut:

1. Melindungi profesi guru dari praktik layanan pendidikan yang tidak kompeten dan dapat merusak citra profesi guru itu sendiri.

2. Melindungi masyarakat dari praktik pendidikan yang tidak profesional yang akan menghambat upaya peningkatan kualitas pendidikan dan penyiapan SDM di negeri ini.

3. Menjadi wahana penjamin mutu bagi LPTK yang bertugas mempersiapkan calon guru dan juga berfungsi sebagai kontrol mutu bagi pengguna layanan pendidikan.

4. Menjaga lembaga penyelenggara pendidikan dari keinginan internal dan eksternal yang potensial dan menyimpang dari ketentuan yang berlaku. ${ }^{17}$

Jadi sertifikasi adalah proses pemberian sertifikat kepada pendidik dalam hal ini guru yang telah memenuhi standar kompetensi guru dalam upaya meningkatkan kualitas pendidikan. Secara logika, apabila kompetensi bagus disertai dengan kesejahteraan ekonomi yang baik, maka tentu seorang guru akan melakukan tugasnya dengan semangat dan baik terutama dalam kegiatan proses pemebelajaran. Sehingga dalam upaya peningkatan kualitas pendidikan di madrasah akan termanifestasi.

\section{Beberapa Faktor Penghambat dan Pendukung Pelaksanaan Sertifikasi}

Dalam pelakasanan sertifikasi terdapat beberapa faktor pendukung dan penghambat. Seperti paparan di bawah ini:

a. Faktor pendukung

Selain disahkannya Undang-undang/ peraturan tentang sertifikasi faktor pendukung lainnya adalah sebagi berikut:

1. Jabatan fungsioanal diharapkan menjadi daya pikat tersendiri terhadap profesi guru. Daya pikat itu merefleksi masyarakat untuk memberikan makna tersendiri baik dalam membangkitkan rasa motivasi diri maupun dalam usaha mencari bibitbibit guru yang berkualitas. ${ }^{18}$

2. Pendidikan pra jabatan

1) Untuk meyakinkan pemilikan kemampuan profesional awal, saringan calon peserta pendidikan pra jabatan perlu dilakukan secara efektif, baik dari

\footnotetext{
${ }^{16}$ Suyatno, Panduan Sertifikasi Guru...hlm. 3.

${ }^{17}$ Abdullah Idi dan Toto Suharto, Revitalisasi Pendidikan Islam (Yogyakarta: Tiara Wacana, 2006), hlm.9.

${ }^{18}$ Syafruddin Nurdin dan Usman, Guru Profesional Implementasi Kurikulum (Jakarta: Ciputat Pers, 2002), hlm. 26.
} 
kemampuan potensial maupun aspek-aspek kepribadian yang relevan serta motivasi.

2) Pendidikan pra jabatan harus benar-benar secara sistematis menyiapkan calon guru untuk menguasai kemampuan profesional.

3) Mekanisme pembinaan dalam jabatan, dengan upaya perlu dikembangkannya mekanisme dan prosedur penghargaan aspek layanan ahli keguruan, perlu adanya penyesuaian-penyesuaian-penyesuain secara mendasar terhadap sistem pengawasan di Madrasah dan adanya keterbukaan informasi untuk meraih kualifikasi yang lebih tinggi.

4) Peranan organisasi profesi, yakni adanya tekad untuk mengangkat jabatan guru sebagai karir profesional, hendaknya dimaknai sebagai upaya sistemastis, konsisten dan terjangkau oleh berbagai pihak terkait. ${ }^{19}$

b. Faktor penghambat

Peningkatan kulitas guru merupakan upaya yang amat kompleks, karena melibatkan banyak komponen. Dalam hal ini LPTK mengalami kesulitan besar kita dihadapkan kepada masalah calon mahasiswa kelas dua ketika akan dididik menjadi guru. Ketidakmampuan LPTK ternyata memang di luar tanggung jawabnya, karena masalah rendahnya mutu calon guru itu lebih disebabkan oleh rendahnya penghargaan terhadap profesi guru. ${ }^{20}$ Gaji dan penghargaan guru belum dapat disejajarkan dengan profesi lain, karena indikasi adanya mutu profesionalime guru masih rendah.

\section{Hasil Penelitian dan Pembahasan}

\section{Beberapa Isu Kontoversial dan Kesenjangan terkait Sertifikasi}

a. Sertifikasi belum mampu meningkatkan kualitas dan kesejahteraan guru

Usaha untuk meningkatkan profesionalitas guru dalam menjalankan tugasnya progam sertifikasi bertujuan baik, salah satunya ekonomi para pendidik semakin baik. Akan tetapi pada kenyataannya, dari sekitar 2,7 juta guru, namun hanya sekitar 350.000 ribu guru yang baru lolos sertifikasi dan mendapatkan tunjangan satu kali gaji. Pemberian ini pun menimbulkan kesenjangan sosial dikalangan guru.

Selain itu, dari hasil pengamatan Kemeterian Agama dan Kementerian Kependidikan Kebudayaan motivasi guru dalam mengikuti seminar, pelatihan, dan sebaiknya tekait peningkatan kualitas komptensi guru, hanya meningkat menjelang sertifikasi. Setelah lulus sertifikasi para guru pun untuk meningkatkan kualitas profesi justru menurun. Seperti pengakuan Maesaroh, guru madrasah di Magelang yang menyatakan bahwa ketika mempersiapkan diklat profesi sertifikasi guru, para guru beramai-ramai mencari materi yang diperlukan akan tetapi setelah menerima tunjangan sertifikasi para guru berlomba-lomba membeli barang-barang mewah seperti kendaraan baru (mobil) untuk digunakan bekerja ke lembaga pendidikannya, meskipun lembaga

\footnotetext{
${ }^{19}$ Syafruddin Nurdin dan Usman, Guru Profesional...hlm. 31.

${ }^{20}$ Suparlan, Guru Sebagai Profesi (Yogyakarta: Hikayat, 2006), hlm. 92-93.
} 
pendidikannya dekat rumah guru itu, bahkan atensi dan motivasi untuk meningkatkan kompetensinya melalui seminar, MGMP, KKG, dan sebagainya cenderung menurun drastis. Bisa dikatakan bahwa beberapa guru mau menerima tunjangan dana sertifikasi nya, akan tetapi dalam urusan peningkatan kemampuan dalam tugasnya tidak.

b. Tunjangan sertifikasi guru masih sebatas janji

Beberapa guru madrasah yang sudah mengikuti program sertifikasi di Kementrian Agama, saat ini belum menerima tunjangan profesional, tidak jelas di mana letak permasalahannya, karena yang muncul ke media massa adalah saling lempar tanggung jawab antar Kementrian Agama dan pemerintah daerah (provinsi) baik kota maupun kabupaten. Beberapa orang daerah mengatakan bahwa dana belum turun, namun orang pusat mengemukakan bahwa dana sudah di drop di daerah, seperti pernyataan Tri Setyowati, seorang guru swasta di Magelang yang mengabdikan diri semenjak tahun 1990 lalu di Madrasah ini meskipun PLPG sudah di ikutinya semenjak tahun 2011 lalu tapi belum juga dibayarkan, hal senada juga di paparkan oleh Mud Arofah, guru swasta yang mengukuti PLPG tahun 2012, tunjangan juga belum dibayarkan .belakangan muncul informasi bahwa tunjangan profesional belum dibayarkan, karena menteri keuangan tidak punya landasan hukum yang mengeluarkannya menanti keputusan dari DPR RI yang mengurusi biaya sertifikasi guru di Kemenag.

c. Pungutan liar dalam sertifikasi

Masalah pungutan dalam sertifikasi kembali mengemuka seperti yang terjadi di Magelang, bahwa dana sertifikasi jika turun akan dipotong beberapa persen sebagai syukuran dan berterima kasih kepada beberapa orang yang terkait pengurusan administrasi sertifikasi. Hal ini dibenarkan oleh Syuheib guru swasta Madrasah di Grabag Magelang, ${ }^{21}$ yang mengaku sudah sertifikasi sejak 2009, akan tetapi setiap kali dana turun sering dipangkas 300 ribu untuk uang lelah pegawai yang mengurus kelancaran sertifikasinya. Program sertifikasi guru dilingkungan Kementerian Agama (Kemenag) Kabupaten Cianjur diduga diwarnai pungutan liar. Bahkan pungutan tidak resmi tersebut diduga dilakukan oleh oknum di Madrasah dan Pendidikan Agama Islam (Mapenda) Cianjur dengan nilai kisaran Rp 2,5 juta.

Menurut penuturan Watimah (26) salah seorang guru Madrasah Ibtidaiyah (MI) diwilayah Cianjur selatan menyebutkan, dia mengaku didatangi oleh oknum guru yang disuruh oknum Mapenda untuk menyetorkan uang sebesar Rp 2,5 juta. Oknum tersebut berdalih uang akan digunakan untuk memuluskan agar lulus sertifikasi. Kondisi tidak jauh berbeda diungkapkan oleh, Dadang Jaenudin, guru Mdrasah Tsanawiyah (MTs) diwilayah Cianjur utara. Dia mengaku tidak dipanggil untuk mengikuti tahapan selanjutnya dalam program sertifikasi lantaran tidak memberikan sejumlah uang. "Saya memang kalah bersaing dengan yang lainnya. Saya tidak memberi uang, sementara setahu saya ada yang sampai memberikan uang. Padahal hemat saya,

${ }^{21}$ Wawancara penulis dengan guru Madrasah Tsanawiyah Grabag Magelang 
saya ini sudah memenuhi semua kreteria dalam program sertifikasi," tegasnya. ${ }^{22}$ Berbeda yang terjadi pada sejumlah guru agama di Kabupaten Situbondo Jawa Timur mengeluhkan adanya pungutan liar yang dilakukan oknum pejabat Kantor Departemen Agama di wilayah itu. Mereka mengaku kaget dan terpaksa membayar uang diluar ketentuan yang berlaku. Pungutan itu dilakukan dengan dalih sebagai uang administrasi. "Kami menerima dana rapelan tunjangan sertifikasi lewat rekening. Tapi setelah menerima, kami diminta Rp 1 sampai Rp 2 juta per orang, katanya uang adimistrasi untuk pejabat Depag yang telah membantu," ujar Arifin, salah seorang guru, Senin (28/12). Guru lainnya, Hamidah, mengaku terpaksa membayar Rp 1,5 juta kepada staf kantor Depag Situbondo karena diancam tunjangan sertifikasi yang diterimanya sejak tahun 2008 akan dicabut. "Posisi kami lemah," katanya. Sejauh ini, praktek pungli menimpa sebanyak 125 orang guru Madrasah Ibtidaiyah (MI), Madarasah Tsanawiyah (Mts) dan Madrasah Aliyah (MA) yang lolos dalam program sertifikasi guru tahun 2007. Arifin menambahkan, ancaman pencabutan tunjangan sertifikasi itu juga dilakukan seiring maraknya jual beli nomor sertifikasi oleh oknum pejabat Depag. " Jika ada guru yang ingin mengganti nomor sertifikasi diminta membayar uang Rp 400 ribu hingga Rp 1 juta," kata arifin. ${ }^{23}$

d. Pelaksanaan sertifikasi yang masih kontroversial dan lamban yang menyebabkan kesenjangan sosial sesama guru.

Usaha untuk meningkatkan kesejahteraan guru dalam tugasnya dilakukan dengan memberikan tunjangan profesional bagi yang telah lulus sertifikasi. Dalam hal ini Undang-undang Nomor 14. tahun 2005 tentang guru dan dosen, sayangya anggaran yang dialokasikan kepada guru-guru sangat terbatas, sehingga memmbuat proses sertifikasi dilakukan secara bertahap, setahun hanya sekitar 200 ribu guru, padahal jumalah guru di negeri ini sekitar 2,7 juta. Dengan demikian mungkin baru sekitar 10 tahun kemudian proses sertifikasi baru selesai. Belum lagi masalah syarat sertifikasi, terutama umur yang lebih tua didahulukan, meskipun ia baru selesai menyelesaikan pendidikannya di bangku kuliah 2012 lalu. Seperti pernyataan di atas seorang guru Madrasah Ibtidaiyah di Magelang yang menuturkan bahwa, saya sudah lulus S1 semnejak 2009 yang lalu akan tetapi ketika melihat longlist di portal web Kementerian Agama selalu tergeser setiap tahun. Dan pergeseran itu diketahui dengan melihat usia peserta sertifikasi. Senada dengan itu, Tolkah ${ }^{24}$ juga memaparkan bahwa di longlist portal Kementerian Agama juga tergeser nomor urutnya dikarenakan setiap tahun ada peserta yang lebih tua masuk longlist.

\footnotetext{
${ }^{22}$ http://www.prianganposcianjur.com/2012/11/pungli-sertifikasi-guru-agama.html. diakses pada tanggal 7/02/2018 pukul 10.00 WIB.

${ }^{23}$ http://www.kesekolah.com/artikel-dan-berita/berita/oknum-depagsitubondo-lakukan pungli.html. dikases pada tanggal 7/02/2018 pukul 10.00 WIB.

${ }^{24}$ Wawancara penulis dengan seorang guru Madrasah Ibtidaiyah di Magelang.
} 


\section{E. Kesimpulan}

Sertifikasi adalah proses pemberian sertifikat kepada seorang pendidik yang mempunyai persayaratn tertentu, memilki kompetensi, kualifikasi akademik, sehat jasmani dan rohani serta memiliki kemampua untuk mewujudkan tujuan pendidikan nasional. Selain mendapatkan sertifikat sebagai guru profesional, pemerintah juga memberikan apresiasi berupa peningkatan kesejahteraan berupa tunjangan keprofesian.

Seorang yang ingin memiliki sertifikat pendidik harus mengikuti program pendidikan profesi guru dan uji kompetensi.

Menurut Suparman, lulusan dari LPTK yang baik sebenarnya berkualitas permasalahannya ketika mereka turun ke lapangan (lembaga pendidikan). ${ }^{25}$ Berikut ini sekaligus usulan kebijakannya:

1. Peningkatan kualitas guru, guru sehaurusnya diberi dukungan dan kebebasan dalam mengembangkan pendidikan setinggi-tingginya. Pemerintah seharusnya memberikan beasiswa bagi guru, kegiatan ilmiah, seminar dan diklat untuk peningkatan komptensi guru.

2. Peningkatan kesejahteraan guru, di sekitar kita masih banyak kita temui beberapa guru yang bergaji dibawah standar, terutama guru swasta dan honorer, sehingga logikanya bagaimana guru bisa mengembangkan potensi jika kondisi ekonominya juga maih lemah.

3. Menghapus diskriminasi status guru yang saat ini beragam, seperti PNS, pegawai honorer dari pusat dan daerah, bahkan masih ada guru yang masih suka rela. Mereka sama-sama mengemban tugas yang sama yakni mencerdasakn bangsa, akan tetapi imbalannya berbeda.

\section{Daftar Pustaka}

Abdullah Idi dan Toto Suharto, 2006. Revitalisasi Pendidikan Islam, Yogyakarta: Tiara Wacana.

Anwar Jasin, 1990. Pengembangan Standar Profesional Guru dalam Rangka Peningkatan Mutu Sumber Daya Manusia, dalam M. Dawam Rahajo, (ed.), Keluar dari Kemeut Pendidikan Nasional: Menjawab Tantangan Kualitas Sumber Daya Manusia Abad (SDM) 21, Jakarta: PT Intermasa.

Burhanuddin, dkk. 1995. Profesi Keguruan, Malang, IKIP malang,

Dedi Supriadi, 1998.Mengangkat Citra dan Martabat Guru, Yogyakarta: Adicita Karya Nusa.

Departemen Pendidikan Nasional. 2009.Undang-Undang RI No 14 tahun 2005 tentang Guru dan Dosen, Bandung: Citra Umbara. hlm. 42 .

${ }^{25}$ Martinis Yamni, Sertifikasi Profesi Keguruandi Indonesia (Jakarta: Gaung Persada Pers, cet II, 2007) 
Ihkwanah, 2011. Bunga Rampai Pendidikan Islam, Surabaya: Taruna Media Pustaka.

Khareuddin dan Mahfudz Junaedi, 2007. Kurikulum Tingkat Satuan Pendidkan dan Implementasinya di Madrasah, Semarang: MDC Jateng Kerjasama dengan pilar Media Yogyakarta, cet.II.

Martinis Yamni, 2007. Sertifikasi Profesi Keguruandi Indonesia, Jakarta: Gaung Persada Pers, cet II.

Masnur Muslich, 2007. Sertifikasi Guru Menuju Profesionalisme Pendidik, Jakarta: Bumi Aksara.

Masnur Muslich, 2007. Sertifikasi Guru Menuju Profesionalisme Pendidik, Jakarta: PT Bumi Aksara.

Mujtahid, 2009. Pengembangan Profesi Guru, Malang: UIN Maliki Press.

Omar Malik, 1991. Pendidikan Guru, Konsep dan Strategi, Bandung: Mandar Maju.

Suparlan, 2006.Guru Sebagai Profesi, Yogyakarta: Hikayat.

Suyatno, 2008. Pandun Sertifikasi Guru, Jakarta: PT Indeks.

Syafruddin Nurdin dan Usman, 2002.Guru Profesional Implementasi Kurikulum, Jakarta: Ciputat Pers. 